\title{
Epoxidation of methyl esters derived from Jatropha oil: An optimization study
}

\author{
By M. Mushtaq ${ }^{1, *}$, Isa M. Tan ${ }^{1}$, M. Nadeem ${ }^{2}$, C. Devi ${ }^{1}$, S.Y. C. Lee ${ }^{1}$, M.Sagir ${ }^{1}$ and U. Rashid ${ }^{3, *}$ \\ ${ }^{1}$ Chemical Engineering Department, Universiti Technologi PETRONAS, \\ Bandar Sari Iskandar 31750, Tronoh, Perak, Malaysia \\ ${ }^{2}$ Subsurface Technology, PETRONAS Research Sdn. Bhd (PRSB), Kajang 43000, Selangor, Malaysia \\ ${ }^{3}$ Institute of Advanced Technology, Universiti Putra Malaysia, Serdang 43400, Selangor, Malaysia \\ * Corresponding authors: mmushtaq3@gmail.com; umer.rashid@yahoo.com
}

\begin{abstract}
RESUMEN
Epoxidación de ésteres metílicos derivados del aceite de Jatropha: Optimización del estudio

Se ha evaluado la optimización de la reacción de epoxidación de ésteres metílicos obtenidos a partir de aceite de Jatropha. Se ha empleado para el diseño experimental una metodología de superficie de respuesta (RSM), basada en un diseño compuesto central giratorio (CCRD). Cuatro variables de la reacción fueron evaluadas: relación molar peróxido de hidrógeno $/ C=C$, relación molar ácido fórmico $/ C=C$, temperatura de reacción y tiempo de reacción. Las condiciones óptimas de epoxidación calculadas por el modelo cuadrático fueron 3.12 moles de peróxido de hidrógeno/ $\mathrm{C}=\mathrm{C}$ moles, 0.96 moles de ácido fórmico/ $\mathrm{C}=\mathrm{C}$ moles, una temperatura de reacción de $70.0^{\circ} \mathrm{C}$ y un tiempo de reacción de 277 minutos. Una reacción optimizada mediante los parámetros propuestos del proceso proporciona un rendimiento de $92.89 \pm 1.29 \%$ en peso con un tiempo de reacción relativamente mejorado. La concentración de peróxido de hidrógeno y la temperatura de la reacción fueron las variables más significativas, además la temperatura de la reacción y la concentración de peróxido de hidrógeno mostraron fuertes interacciones. Los ésteres metílicos epoxidados se analizaron mediante FT-IR, 1H RMN y RMN de 13C. Este estudio indica que se requiere una proporción molar relativamente mayor de ácido fórmico que la propuesta en la literatura.
\end{abstract}

PALABRAS CLAVE: Aceite epoxidado de Jatropha Caracterización - Metodología de superficie - Optimización - Respuesta.

\section{SUMMARY}

Epoxidation of methyl esters derived from Jatropha oil: An optimization study

The optimization of the epoxidation reaction of methyl esters obtained from Jatropha oil was appraised. Response surface methodology (RSM) based on a central composite rotatable design (CCRD) was employed for the experimental design. Four reaction variables namely hydrogen peroxide/ $\mathrm{C}=\mathrm{C}$ mole ratio, formic acid $/ \mathrm{C}=\mathrm{C}$ mole ratio, reaction temperature and reaction time were evaluated. The optimum epoxidation conditions calculated by the quadratic model were 3.12 moles of hydrogen peroxide $/ C=C$ moles, 0.96 moles of formic acid $/ \mathrm{C}=\mathrm{C}$ moles, a reaction temperature of $70.0{ }^{\circ} \mathrm{C}$ and a reaction time of 277 minutes. A reaction optimized by the proposed process parameters provided a yield of $92.89 \pm 1.29$ wt. $\%$ with relatively improved reaction time. Hydrogen peroxide concentration and reaction temperature were found to be the most significant variables while reaction temperature and hydrogen peroxide showed strong interactions. The epoxidized methyl esters were analyzed using FT-IR, ${ }^{1} \mathrm{H}$ NMR and ${ }^{13} \mathrm{C}$ NMR techniques. This study suggested relatively higher molar ratio of formic acid required than was proposed in the literature.

KEY-WORDS: Characterization - Epoxidised Jatropha oil - Optimization - Response surface methodology.

\section{INTRODUCTION}

The epoxidation reaction in natural oils and alkyl esters has gained prominence in recent years due to its multifarious usage in many industrial synthetic processes. As natural products are being used extensively in recent years due to the depletion of petroleum reserves and environmental concerns (Ibrahim et al., 2011, Anwar et al., 2006), the epoxidation reaction is gaining more importance as a reaction route in natural oils, fatty acid methyl esters and related oleo chemical conversions (Seniha Güner et al., 2006). Products such as polymers, resins, biodiesel, cutting oils, high-tech surfactants, lubricating oils and nano composites benefit from the epoxidation reaction (Kleinová et al., 2008, Dahlke et al., 1995, Doll and Erhan, 2006).

Traditionally, an organic acid such as acetic or formic acid is used with hydrogen peroxide to generate per oxyacid as the oxygen carrier for the epoxidation of oils and fatty acid alkyl esters (Du et al., 2004). These per oxyacids can be employed as a separate reagent or can be synthesized insitu, but the most common method is the in-situ generation of peroxy acid. Nevertheless, many heterogeneous catalysts and enzymes have been suggested and employed to augment the effects of organic acids and hydrogen peroxide to enhance the yield. It was also found that peroxy formic acid was more efficient than peroxy acetic acid (Du et al., 2004, Mungroo et al., 2008).

A schematic representation of the epoxidation reaction is presented in Figure 1. In the course of the epoxidation reaction, an epoxidized product can undergo a ring opening reaction which is highly undesirable. This ring opening reaction has 


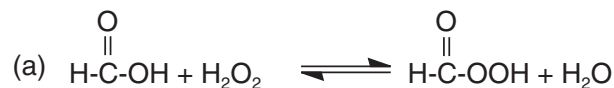

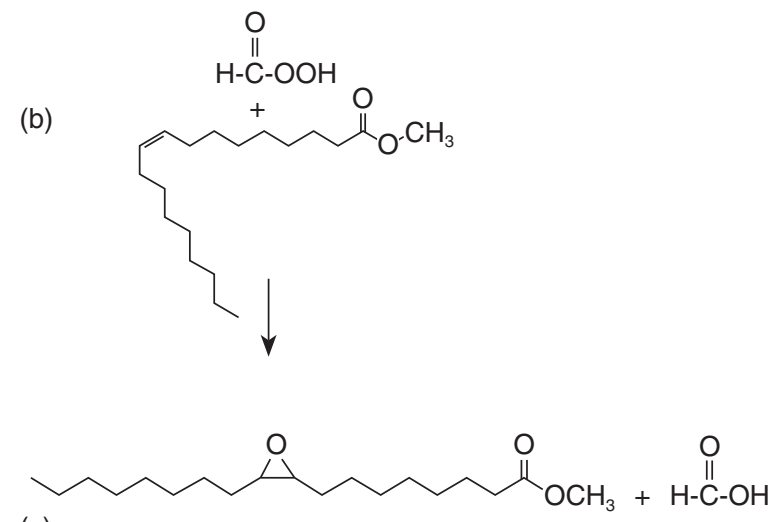

(c)

$+$

(Regenerated)

$\mathrm{RH}$<smiles>[R]C(CCCCCCCC(=O)OC)C(O)CCCCCCCC</smiles>

$\mathrm{R}=-\mathrm{OH},-\mathrm{OOH},-\mathrm{OCOH},-\mathrm{OOCOH}$

Figure 1

(a) In-situ generation of peroxy formic acid, (b) epoxidation of oleic acid methyl ester, (c) degradation of oxirane ring (Gan et al., 1992, Campanella et al., 2008a).

been investigated extensively and various studies have been reported on the kinetics of ring opening reactions (Campanella and Baltanás, 2006, Khlebnikova et al., 2009). The ring opening reaction is associated with the presence of hydrogen peroxide and formic acid at elevated reaction temperatures (Gan et al., 1992). To overcome this hindrance, some researchers have tried organic solvents such as benzene and toluene. Goud et al., and Mungroo et al. used organic acids and hydrogen peroxide with ion exchange resins for the epoxidation reaction in the presence and absence of toluene as solvent (Goud et al., 2007, Mungroo et al., 2008). The solvent has been found to be beneficial in minimizing the ring opening reaction. Moreover, it has also been demonstrated by several researches by conducting kinetic studies that although the rate of opening of oxiranes can been reduced in the presence of solvent, the conversion efficiency has been compromized (Goud et al., 2010). The reaction temperature is also an important parameter in this reaction. Campanella et al. (2008a) studied the effect of high temperature and it was shown that an increase in temperature during the course of the reaction was found to be detrimental for the epoxidation reaction as the ring opening process is facilitated at higher temperatures. Therefore, a careful control of the amount of reactants and reaction temperature is vital for achieving a high yield of epoxidation. Despite the fact that the reaction time is one of the most important factors governing the reaction progress both in epoxidation and ring opening terms, it has not been studied for optimization. Longer reaction times (more than 20 hours) have been used for the epoxidation reaction (Campanella et al., 2008a) with low reaction temperatures.

Response surface methodology (RSM) is a collection of statistical and mathematical methods that can be used for solving engineering optimization problems. It is gaining popularity due its strong ability to optimize the reaction parameters in a production design by quantifying the relationships between controllable input parameters and obtaining the response factors (Aslan, 2008).

RSM has been applied in many process optimizations such as biodiesel production, adsorption processes, synthesis of oleo chemicals and catalyst development (Jiang and Niu, 2011, Ghadge and Raheman, 2006). However, there are scarce reports on the optimization of the epoxidation of oils and alkyl esters (Sun et al., 2011, Naidir et al., 2011). Methyl esters obtained from Jatropha oil have been studied in this work. In recent years, it has been extensively investigated for bio-diesel synthesis (Brossard-González et al., 2010, Kumar and Sharma, 2008). According to our knowledge no optimization study on the epoxidation of Jatropha oil using RSM has yet been reported. This study presents the application of RSM for the optimization of epoxidation reaction parameters along with their role and significance in the reaction. The influence of reaction variables (i.e. hydrogen peroxide $/ \mathrm{C}=\mathrm{C}$ mole ratio, formic acid/C $=\mathrm{C}$ mole ratio, reaction temperature and reaction time) on the yield of the epoxidized product were examined. The effects of these parameters on the conversion to the epoxidized oil were studied and optimum conditions were found. Furthermore, the characterization of epoxidized Jatropha oil was determined using FTIR, ${ }^{1} \mathrm{H}$ NMR and ${ }^{13} \mathrm{C}$ NMR techniques.

\section{MATERIALS AND METHODS}

Jatropha oil was obtained from BATC Development Bhd., Malaysia. Sodium methoxide, methanol and Hydrogen peroxide ( $30 \%$ solution) were Analytical Reagent (AR) grade from Fisher Scientific. Formic acid and sodium bicarbonate were obtained from Merck. The hexane, anhydrous sodium sulfate and sodium chloride used were also ACS grade and obtained from J.T Baker. All materials were used as received without further purification.

\subsection{Experimental design}

Four variables i.e. hydrogen peroxide $/ \mathrm{C}=\mathrm{C}$ molar ratio $\left(\mathrm{H}_{2} \mathrm{O}_{2}\right.$ moles), formic acid/C=C molar ratio (formic acid moles), reaction temperature and reaction time were selected as the reaction variables and the epoxidation yield was designated as the response factor. Design Expert software version 8.0.7.1 from Stat-Ease Inc. Minneapolis, 
USA was used for the experimental design and to analyze the statistical data.

The ranges of designed reaction variables comprised for 1 mole of $\mathrm{C}=\mathrm{C}$ were as follows: hydrogen peroxide (0.5-4 moles), formic acid (0.202.0 moles), reaction temperature $\left(25-85^{\circ} \mathrm{C}\right)$ and reaction time (30-360 minutes). All experiments were conducted at a fixed stirring speed of 1500 rpm which was found to be the optimum in our lab experiments and also reported in previous studies (Goud et al., 2006). The range and levels for each parameter with its respective symbol are shown in Table 1. The epoxidation yield (\%) was taken as the response variable, defined by the following expression (Equation 1):

$$
\text { Epoxidation yield }(\%)=\frac{O_{\exp }}{O_{\text {theo }}} \times 100
$$

Where, $O_{\text {exp }}$ and $O_{\text {theo }}$ are the experimental and theoretical oxirane oxygen values (\%) respectively. The amount of $O_{\exp }$ (oxirane oxygen \%) was determined using the AOCS official method $\mathrm{Cd}$ 9-57 and the $\mathrm{O}_{\text {theo }}$ was calculated using Equation 2.

With an iodine value of $101.3 \mathrm{~g} \mathrm{I}_{2} 100 \mathrm{~g}^{-1}$ of methyl esters, the theoretical oxirane oxygen for methyl esters was calculated to be $6.0 \%$ using the expression presented in Equation 2 (Campanella et al., 2008b).

$$
O_{\text {theo }}=\left[\frac{(I V / 253.8)}{[100+(I V / 253.8) 16]}\right] \times 16 \times 100
$$

Where $I V$ is lodine value $\left(\mathrm{g} \mathrm{I}_{2} 100 \mathrm{~g}^{-1}\right.$ methyl esters). lodine value was determined by employing Wijs solution, according to the AOCS standard method Cd-1d-92.

Full factorial CCRD for four independent variables at five levels proposed 30 experimental runs using the equation $2^{k}+2 k+6$ where $k$ is the number of independent variables. The experimental design contained eight axial points, sixteen factorial points and six center points. Center points are the replicates of trials for the estimation of experimental error.

\subsection{Transesterification of jatropha oil}

Transesterification with methanol was conducted according to the process reported in a previous study
(Rashid et al., 2012). The product was cleaned and dried for its use in an epoxidation reaction. Methyl ester purity in terms of free and bound glycerol contents was confirmed according to ASTM D 658400 using a Shimadzu GC 2010 system fitted with an FID-2010. The results of the purity of methyl esters are presented in Table 2.

\subsection{Epoxidation process}

The epoxidation reaction was conducted at a selected temperature for a specific reaction time by utilizing the peroxy formic acid generated insitu when hydrogen peroxide reacts with formic acid. The reaction was carried out in a $1000 \mathrm{~mL}$ three-neck round bottom Pyrex flask equipped with a magnetic stirrer placed in a temperature controlled bath on a hotplate/stirrer assembly. The mixture of methyl esters and formic acid was stirred continuously at a fixed speed of 1500 rpm; the required amount of hydrogen peroxide was added drop by drop in the course of 30-45 minutes at room temperature. The mixture was gradually heated to the required temperature and kept at a constant temperature for the selected reaction time.

After that, the mixture was transferred to a separating funnel and the aqueous layer was drained immediately. The product was washed with a saturated sodium bicarbonate solution, distilled water and a saturated sodium chloride solution in sequence. After water removal, the product was diluted in hexane and dried over anhydrous sodium sulfate. The hexane was removed by vacuum distillation.

\subsection{Characterization of the product}

The fatty ester profile was determined by GCMS with an Agilent 7890A GC System coupled with an Agilent 5975C inert XL El/CI MSD with TripleAxis Detector. The capillary column was BP5, 30 $\mathrm{m} \times 250 \mu \mathrm{m} \times 0.25 \mu \mathrm{m}$. The oven temperature program was as follows: $3 \mathrm{~min}$ at $100{ }^{\circ} \mathrm{C}, 25^{\circ} \mathrm{C}$ $\mathrm{min}^{-1}$ to $170{ }^{\circ} \mathrm{C}, 2{ }^{\circ} \mathrm{C} \mathrm{min}$ mi $^{-1}$ to $230^{\circ} \mathrm{C}, 20^{\circ} \mathrm{C} \min ^{-1}$ to $250^{\circ} \mathrm{C}$ and maintained at $250^{\circ} \mathrm{C}$ for 10 minutes (Wilson et al., 1997). Helium was used as the carrier gas with a flow rate of $0.5 \mathrm{~mL} \mathrm{~min}^{-1}$.

The quantification of the epoxide product was also verified by GC-MS as described above under

Table 1

\begin{tabular}{|c|c|c|c|c|c|c|}
\hline \multirow[b]{2}{*}{ Variable } & \multirow[b]{2}{*}{ Symbol } & \multicolumn{5}{|c|}{ Coded variable level } \\
\hline & & $\begin{array}{c}\text { Lowest } \\
-2\end{array}$ & $\begin{array}{c}\text { Low } \\
-1\end{array}$ & $\begin{array}{c}\text { Centre } \\
0\end{array}$ & $\begin{array}{c}\text { High } \\
1\end{array}$ & $\begin{array}{c}\text { Highest } \\
2\end{array}$ \\
\hline Hydrogen peroxide/C=C ( mole ratio) & $X_{1}$ & 0.5 & 1.375 & 2.25 & 3.125 & 4.0 \\
\hline Formic acid/C=C ( mole ratio) & $X_{2}$ & 0.20 & 0.65 & 1.1 & 1.55 & 2.0 \\
\hline Temperature $\left({ }^{\circ} \mathrm{C}\right)$ & $X_{3}$ & 25 & 40 & 55 & 70 & 85 \\
\hline Reaction time (min) & $X_{4}$ & 30 & 112.5 & 195 & 277.50 & 360 \\
\hline
\end{tabular}

Range and levels of reaction parameters for CCRD 
Table 2

Glycerol and glyceride contents of methyl esters

\begin{tabular}{lc}
\hline \multicolumn{1}{c}{ Species } & Amount (wt. \%) \\
\hline Free glycerol & 0.012 \\
Mono glycerides & 0.68 \\
Di glycerides & 0.11 \\
Tri glycerides & 0.13 \\
Total glycerides & 0.932 \\
\hline
\end{tabular}

the methyl ester profile analysis. Enough time was given at $250{ }^{\circ} \mathrm{C}$ to elute all the necessary peaks. ${ }^{1} \mathrm{H}$ NMR and ${ }^{13} \mathrm{C}$ NMR analyses were performed using the Bruker Ultrashield 400 at $400 \mathrm{MHz}$. FT- IR spectra were obtained by Perkin Elmer Spectrum One FT-IR spectrometer equipped with a $\mathrm{ZnSe} 45^{\circ}$ HATR assembly. An average of 30 scans was used with spectral resolution of $4 \mathrm{~cm}^{-1}$ over the range of $4000-600 \mathrm{~cm}^{-1}$.

\subsection{Statistical analysis}

The experiments were performed according to the model design and the response variable (\% yield) was analyzed by fitting a second-order model polynomial equation as shown below:

$y_{\text {yield }}=b_{0}+\sum_{i=1}^{k} b_{i} X_{i}+\sum_{i=1}^{k} b_{i i} X_{i}^{2}+\sum_{i>j}^{k} \sum_{j}^{k} b_{i j} X_{i} X_{j}+e$

Where, $y_{\text {yield }}$ is the predicted response variable (Epoxidation yield \%), $i$ and $j$ are the linear and quadratic coefficients respectively, $b$ is the regression coefficient, $k$ is the number of factors studied for experimental optimization, $X_{i}$ and $X_{i}$ are uncoded independent variables, and $e$ is the random error.

\section{RESULTS AND DISCUSSIONS}

\subsection{Characteristics of methyl esters}

The profile of methyl esters with major fatty esters was as follows:

C16:0 $=13.5 \%$, C18:0 $=7.1 \%$, C $18: 1=44.3 \%$, $\mathrm{C} 18: 2=32.8 \%$. Methyl esters had an lodine value of $101.3 \mathrm{mg} \mathrm{l}_{2} \mathrm{~g}^{-1}$ methyl esters.

\subsection{Optimization of the reaction conditions by RSM}

Four reaction variables, namely hydrogen peroxide concentration, formic acid concentration, temperature and reaction time were studied and evaluated. A set of thirty experiments were performed according to the central composite rotatable design (CCRD). The experimental design with compositions of experimental variables and the experimentally observed results as well as the predicted results for all runs are presented in Table 3. The response obtained was correlated with four independent variables using a polynomial equation (3). The data obtained by CCRD were used to fit an empirical quadratic model and multiple regression analysis of the experimental data produced the second degree polynomial equation (in terms of coded factors) for the yield of epoxidized methyl esters as shown below:

$$
\begin{aligned}
& y=+72.00+11.66 X_{1}-2.14 X_{2}+9.48 X_{3}+ \\
& +8.50 X_{4}-0.82 X_{1} X_{2}+4.48 X_{1} X_{3}+1.52 X_{1} X_{4}+ \\
& +1.64 X_{2} X_{3}-2.04 X_{2} X_{4}+1.39 X_{3} X_{4}-5.03 X_{1}^{2}- \\
& -4.59 X_{2}^{2}-4.82 X_{3}^{2}-4.87 X_{4}^{2}
\end{aligned}
$$

Here $y$ is the response factor (Epoxidation yield \%), and $X_{1}, X_{2}, X_{3}$ and $X_{4}$ are the coded values of the test variables hydrogen peroxide concentration, formic acid concentration, reaction temperature and reaction time respectively. The terms $X_{1} X_{2}, X_{1} X_{3}$, $X_{1} X_{4}, X_{2} X_{3}, X_{2} X_{4}, X_{3} X_{4}$ are the first order interaction terms for each paired combination showing interactions among the pre-defined variables.

The results of the analysis of variance (ANOVA) for fitting the second-order response surface model by the least-squares method is presented in Table 4. A high statistical significance is required for a model to be considered fit for its reliable application. High significance of a model was indicated by a high $F_{\text {model }}$ value of 94.83 at a very low probability $p$ $<0.0001$ implying that the model fit was significant with only $0.01 \%$ chance that $F_{\text {model }}$ value of 94.83 could be attributed to noise. In addition, the lack of fit condition for the model was not significant and fitness of model was also evaluated by calculating the regression equation and the multiple correlation co-efficient $R^{2}$. A high value of $R^{2}=0.9888$ indicated that $98.88 \%$ of the response variable (Epoxidation yield) was dependent on the independent variables $\left(X_{1}, X_{2}, X_{3}\right.$ and $\left.X_{4}\right)$ and only $1.12 \%$ of total variations were dependent on other variables not defined by the model. Moreover, high $R^{2}$ indicated that this model could be used with reliability to predict results with good precision. The high reliability of results from the model was also supported by low coefficients of variance $(\mathrm{CV}=4.75 \%)$. A low $\mathrm{CV}$ indicates high precision, low scatter and better repeatability in experimental results. In addition, a high value of adjusted determination coefficient (Adj. $R^{2}=0.9784$ ) also indicated the high significance of the model.

The Normal Plot of Residuals is shown in Figure 2 and indicates the normal distribution of residuals. The points should follow a straight line with a normal, acceptable scatter if their distribution is normal. The plot shows that the data distribution is essentially normal. In Figure 3, a plot of actual values against the values predicted by the model is presented. Most of the data points are evenly distributed along the line showing a high value for $R^{2}(0.9888)$ and excellent agreement between experimental results and the predicted values for the model. 
Table 3

Full Factorial Central Composite Rotatable Design (CCRD) matrix of four variables in coded and natural units along with the observed and predicted responses (\% epoxidation)

\begin{tabular}{|c|c|c|c|c|c|c|c|c|c|c|c|c|}
\hline \multirow{2}{*}{$\begin{array}{l}\text { Standard } \\
\text { order }\end{array}$} & \multirow{2}{*}{$\begin{array}{l}\text { Point } \\
\text { type }\end{array}$} & \multicolumn{4}{|c|}{$\begin{array}{l}\text { Coded level } \\
\text { of variables }\end{array}$} & \multicolumn{4}{|c|}{ Actual level of variables } & \multicolumn{2}{|c|}{ Epoxidation yield (\%) } & \multirow[b]{2}{*}{ Residuals } \\
\hline & & $X_{1}$ & $X_{2}$ & $X_{3}$ & $X_{4}$ & $\begin{array}{c}\text { Hydrogen } \\
\text { peroxide/C=C } \\
\text { mole ratio }\end{array}$ & $\begin{array}{c}\text { Formic } \\
\text { acid } / C=C \\
\text { mole ratio }\end{array}$ & $\begin{array}{c}\text { Reaction } \\
\text { temperature } \\
\left({ }^{\circ} \mathrm{C}\right)\end{array}$ & $\begin{array}{c}\text { Reaction } \\
\text { time } \\
\text { (min) }\end{array}$ & $\begin{array}{c}\text { Actual } \\
\text { value } \\
\text { (wt. \%) }\end{array}$ & $\begin{array}{l}\text { Predicted } \\
\text { value } \\
\text { (wt. \%) }\end{array}$ & \\
\hline 1 & Factorial & -1 & -1 & -1 & -1 & 1.375 & 0.65 & 40 & 112.5 & $30.45 \pm 0.92$ & 31.34 & -0.89 \\
\hline 2 & Factorial & 1 & -1 & -1 & -1 & 3.125 & 0.65 & 40 & 112.5 & $45.22 \pm 0.68$ & 44.32 & 0.90 \\
\hline 3 & Factorial & -1 & 1 & -1 & -1 & 1.375 & 1.55 & 40 & 112.5 & $30.43 \pm 0.93$ & 29.51 & 0.92 \\
\hline 4 & Factorial & 1 & 1 & -1 & -1 & 3.125 & 1.55 & 40 & 112.5 & $37.22 \pm 1.36$ & 39.19 & -1.97 \\
\hline 5 & Factorial & -1 & -1 & 1 & -1 & 1.375 & 0.65 & 70 & 112.5 & $35.38 \pm 0.89$ & 35.28 & 0.10 \\
\hline 6 & Factorial & 1 & -1 & 1 & -1 & 3.125 & 0.65 & 70 & 112.5 & $65.69 \pm 1.83$ & 66.18 & -0.49 \\
\hline 7 & Factorial & -1 & 1 & 1 & -1 & 1.375 & 1.55 & 70 & 112.5 & $37.29 \pm 1.27$ & 40.01 & -2.72 \\
\hline 8 & Factorial & 1 & 1 & 1 & -1 & 1.375 & 1.55 & 40 & 277.5 & $35.14 \pm 0.68$ & 36.61 & -1.47 \\
\hline 9 & Factorial & -1 & -1 & -1 & 1 & 3.125 & 1.55 & 40 & 277.5 & $50.45 \pm 1.06$ & 52.37 & -1.92 \\
\hline 10 & Factorial & 1 & -1 & -1 & 1 & 1.375 & 0.65 & 70 & 277.5 & $56.11 \pm 0.93$ & 56.10 & 0.01 \\
\hline 11 & Factorial & -1 & 1 & -1 & 1 & 3.125 & 0.65 & 70 & 277.5 & $90.34 \pm 1.83$ & 93.07 & -2.73 \\
\hline 12 & Factorial & 1 & 1 & -1 & 1 & 1.375 & 1.55 & 70 & 277.5 & $49.94 \pm 1.25$ & 52.66 & -2.72 \\
\hline 13 & Factorial & -1 & -1 & 1 & 1 & 3.125 & 1.55 & 70 & 277.5 & $85.27 \pm 1.46$ & 86.34 & -1.07 \\
\hline 14 & Factorial & 1 & -1 & 1 & 1 & 0.5 & 1.1 & 55 & 195 & $30.22 \pm 0.73$ & 28.56 & 1.66 \\
\hline 15 & Factorial & -1 & 1 & 1 & 1 & 4 & 1.1 & 55 & 195 & $77.34 \pm 1.25$ & 75.22 & 2.12 \\
\hline 16 & Factorial & 1 & 1 & 1 & 1 & 2.25 & 0.2 & 55 & 195 & $57.34 \pm 1.05$ & 57.90 & -0.56 \\
\hline 17 & Axial & -2 & 0 & 0 & 0 & 2.25 & 2 & 55 & 195 & $53.67 \pm 1.31$ & 49.33 & 4.34 \\
\hline 18 & Axial & 2 & 0 & 0 & 0 & 1.375 & 0.65 & 40 & 112.5 & $30.45 \pm 0.29$ & 31.34 & -0.89 \\
\hline 19 & Axial & 0 & -2 & 0 & 0 & 3.125 & 0.65 & 40 & 112.5 & $45.22 \pm 1.63$ & 44.32 & 0.90 \\
\hline 20 & Axial & 0 & 2 & 0 & 0 & 1.375 & 1.55 & 40 & 112.5 & $30.43 \pm 1.47$ & 29.51 & 0.92 \\
\hline 21 & Axial & 0 & 0 & -2 & 0 & 2.25 & 1.1 & 25 & 195 & $33.87 \pm 1.58$ & 33.76 & 0.11 \\
\hline 22 & Axial & 0 & 0 & 2 & 0 & 2.25 & 1.1 & 85 & 195 & $75.33 \pm 1.71$ & 71.66 & 3.67 \\
\hline 23 & Axial & 0 & 0 & 0 & -2 & 2.25 & 1.1 & 55 & 30 & $36.44 \pm 0.86$ & 35.50 & 0.94 \\
\hline 24 & Axial & 0 & 0 & 0 & 2 & 2.25 & 1.1 & 55 & 360 & $72.34 \pm 1.22$ & 69.50 & 2.84 \\
\hline 25 & Center & 0 & 0 & 0 & 0 & 2.25 & 1.1 & 55 & 195 & $73.31 \pm 1.69$ & 72.00 & 1.32 \\
\hline 26 & Center & 0 & 0 & 0 & 0 & 2.25 & 1.1 & 55 & 195 & $71.76 \pm 1.33$ & 72.00 & -0.24 \\
\hline 27 & Center & 0 & 0 & 0 & 0 & 2.25 & 1.1 & 55 & 195 & $69.03 \pm 1.96$ & 72.00 & -2.97 \\
\hline 28 & Center & 0 & 0 & 0 & 0 & 2.25 & 1.1 & 55 & 195 & $70.87 \pm 0.92$ & 72.00 & -1.13 \\
\hline 29 & Center & 0 & 0 & 0 & 0 & 2.25 & 1.1 & 55 & 195 & $74.95 \pm 1.66$ & 72.00 & 2.96 \\
\hline 30 & Center & 0 & 0 & 0 & 0 & 2.25 & 1.1 & 55 & 195 & $72.05 \pm 1.57$ & 72.00 & 0.05 \\
\hline
\end{tabular}

\subsubsection{Effects of reaction parameters}

From Table 4, individual experimental parameters $\left(X_{1}, X_{2}, X_{3}\right.$ and $\left.X_{4}\right)$ can be judged for their significance by looking at the corresponding $p$-values. The lower the $p$-values, the higher the significance of the corresponding coefficient will be. The $p$-values also indicate the strength of interaction between the cross product of variables.

Interactions and effects of different variables can be noted by viewing the polynomial model as shown in Equation 4. The positive coefficients of $X_{1}$ (hydrogen peroxide), $X_{3}$ (temperature) and $X_{4}$ (time) and for interaction terms, $X_{1} X_{3}$ (hydrogen peroxide $\times$ reaction temperature), $X_{1} X_{4}$ (hydrogen peroxide $\times$ time ), $X_{2} X_{3}$ (formic acid $\times$ reaction temperature), and $X_{3} X_{4}$ (reaction temperature $\times$ time) indicate a linear effect of increasing the yield of epoxidation, while the negative coefficient of $X_{2}$ (formic acid), interaction terms, $X_{1} X_{2}$ (hydrogen peroxide $\times$ formic acid), $X_{2} X_{4}$ (formic acid $\times$ time), and the quadratic terms $X_{1}^{2}, X_{2}^{2}, X_{3}^{2}$ and $X_{4}^{2}$ have a negative effect and decrease the yield of epoxidation .

Moreover, the effect of these parameters on yield can be observed by looking at the respective $F$-value and $p$-values shown for each parameter 


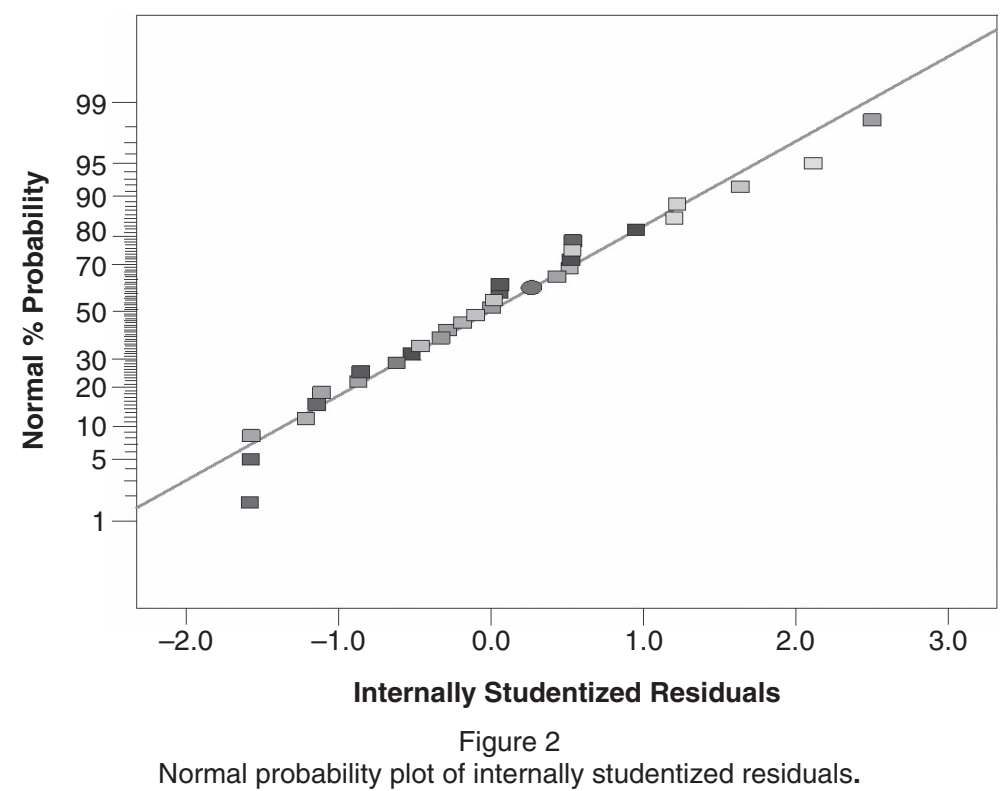

in Table 4. The higher the $F$-value (and lower the $p$-values), the more pronounced the effect of said parameter will be on the yield.

\section{Hydrogen peroxide}

The hydrogen peroxide concentration $\left(\mathrm{H}_{2} \mathrm{O}_{2}\right)$ $\mathrm{C}=\mathrm{C}$ mole ratio) is the most significant first order reaction term. While the role of hydrogen peroxide is directly associated with formic acid, the latter is not as significant as the former is. Hydrogen peroxide is the oxidation agent for generating peroxy formic acid and hydrogen peroxide and formic acid should be equally significant because peroxy formic acid is the product of the two, the former is more important since formic acid can be regenerated from peroxy formic acid after utilizing its oxygen atom (Goud et al., 2010). Therefore, for the generation of peroxyformic acid, hydrogen peroxide concentration is a more important parameter than the formic acid concentration.

\section{Reaction temperature}

The reaction temperature is the second most significant reaction parameter. The first order term of reaction temperature has a more significant effect on the epoxidation reaction than the reaction time and formic acid concentration. The role of reaction temperature in this reaction is manifold: it is important in the generation of peroxy acid (Goud et al., 2006) (the sole oxygen carrier), the epoxidation of the double bond (Mungroo et al., 2008) and then in the opening up the oxirane ring (Lin et al., 2008) (undesired reaction) in the presence of formic acid. At low temperatures, the overall epoxidation reaction is very slow (requiring

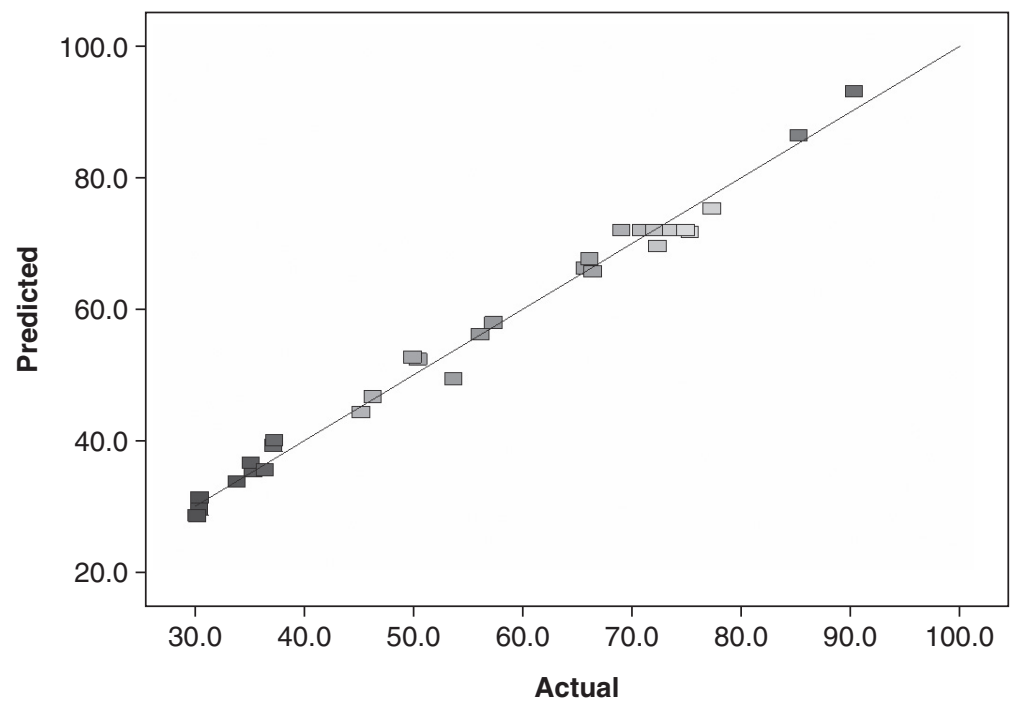

Figure 3

Comparison of actual and predicted values of response. 
Table 4

Analysis of Variance (ANOVA) for the fitted quadratic polynomial model

\begin{tabular}{|c|c|c|c|c|c|}
\hline Source of variations & $\begin{array}{l}\text { Sum of } \\
\text { Squares }\end{array}$ & $\begin{array}{c}\text { Degrees } \\
\text { of Freedom }\end{array}$ & Mean Square & $F$ Value & $\begin{array}{c}P \text { Value } \\
\text { Probability }>\boldsymbol{F}\end{array}$ \\
\hline Model & 9567.267 & 14 & 683.3762 & 94.82924 & $<0.0001$ \\
\hline $\begin{array}{l}\text { Hydrogen peroxide/ } \\
\mathrm{C}=\mathrm{C} \text { mole ratio }\left(X_{1}\right)\end{array}$ & 3265.034 & 1 & 3265.034 & 453.075 & $<0.0001$ \\
\hline $\begin{array}{l}\text { Formic acid/ } \\
\mathrm{C}=\mathrm{C} \text { mole ratio }\left(X_{2}\right)\end{array}$ & 110.1245 & 1 & 110.1245 & 15.28151 & 0.0014 \\
\hline Temperature $\left(X_{3}\right)$ & 2154.805 & 1 & 2154.805 & 299.0131 & $<0.0001$ \\
\hline Reaction time $\left(X_{4}\right)$ & 1733.83 & 1 & 1733.83 & 240.5963 & $<0.0001$ \\
\hline$X_{1} X_{2}$ & 10.84056 & 1 & 10.84056 & 1.504298 & 0.2389 \\
\hline$X_{1} X_{3}$ & 321.3953 & 1 & 321.3953 & 44.59867 & $<0.0001$ \\
\hline$X_{1} X_{4}$ & 36.87526 & 1 & 36.87526 & 5.117024 & 0.0390 \\
\hline$X_{2} X_{3}$ & 43.13206 & 1 & 43.13206 & 5.985254 & 0.0272 \\
\hline$X_{2} X_{4}$ & 66.87151 & 1 & 66.87151 & 9.279477 & 0.0082 \\
\hline$X_{3} X_{4}$ & 30.71931 & 1 & 30.71931 & 4.262789 & 0.0567 \\
\hline$X_{1}^{2}$ & 692.7896 & 1 & 692.7896 & 96.13549 & $<0.0001$ \\
\hline$X_{2}^{2}$ & 578.9963 & 1 & 578.9963 & 80.34487 & $<0.0001$ \\
\hline$X_{3}^{2}$ & 637.4244 & 1 & 637.4244 & 88.45269 & $<0.0001$ \\
\hline$X_{4}^{2}$ & 651.3837 & 1 & 651.3837 & 90.38977 & $<0.0001$ \\
\hline Residual & 108.0958 & 15 & 7.206387 & & \\
\hline Lack of Fit & 87.51946 & 10 & 8.751946 & 2.13 & 0.2095 \\
\hline Pure Error & 20.57635 & 5 & 4.11527 & & \\
\hline Total & 9675.363 & 29 & & & \\
\hline \multicolumn{6}{|c|}{$\mathrm{CV}=4.75 \%, R^{2}=0.9888, R_{\mathrm{adj}}^{2}=0.9784$, predicted $R^{2}=0.9448$} \\
\hline
\end{tabular}

long reaction times) and at a high temperature, yield becomes low when the opening of oxirane ring intensifies. Therefore, a careful control of reaction temperature is highly desired for good epoxidation yields.

\section{Reaction time}

Reaction time also has a very significant role in the epoxidation reaction. As the ring opening reaction is also associated with the ring generation reaction, prolong reaction times promote the former (Campanella et al., 2008a). However, long reaction times at lower temperatures can lead to a high yield of oxirane with a minimum ring opening reaction. Comparatively less significant quadratic terms of reaction time suggest that the effect is almost linear with less curvature effect.

\section{Formic acid concentration}

Formic acid played a less significant role as compared to the other three reaction parameters. This is mainly due to the regenerating nature of this reactant. Therefore, concentration effect is relatively less pronounced than that for hydrogen peroxide. However, in ring opening reactions, the role of formic acid has been presented in the literature (Lin et al., 2008).

The corresponding 2-D contour plots are graphical representations of the regression equation and can be used to assess the significance of different parameters for the optimization of reaction conditions. The contour lines represent the effect of two parameters on response variables by using an infinite number of combinations of these variables while keeping the other two variables constant at some specific level. The surface encircled by the smallest ellipse represents the maximum response (Goswami et al., 2012). Like contour plots, the 3-D response surfaces can also be used for the optimization of parameters. Contour plots of epoxidation yield (wt. \%) predicted from the model are presented in figures 4 a-f.

Figure $4 \mathrm{a}$ shows the effects of hydrogen peroxide formic acid concentrations on yield. The effect of varying the hydrogen peroxide amount is more significant as compared to the effect of changes in the concentrations of formic acid. This supports the vital role played by hydrogen peroxide in generating peroxy formic acid for 
(a)

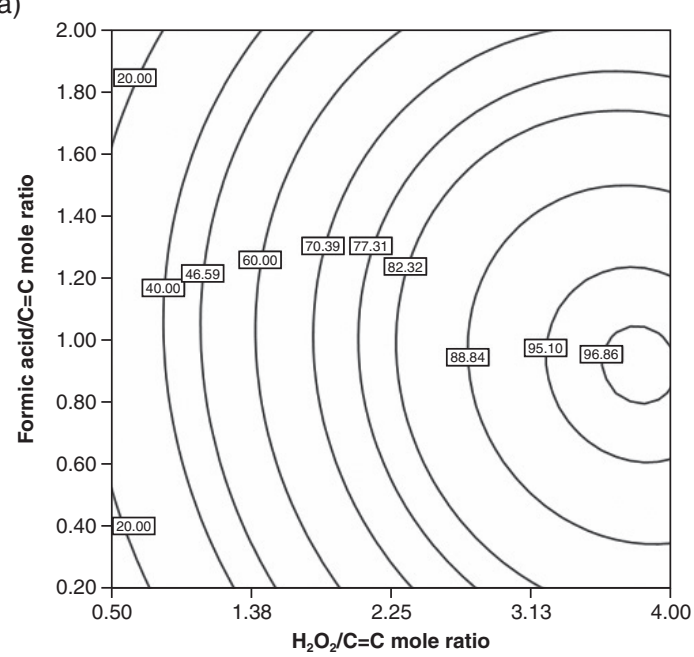

(c)

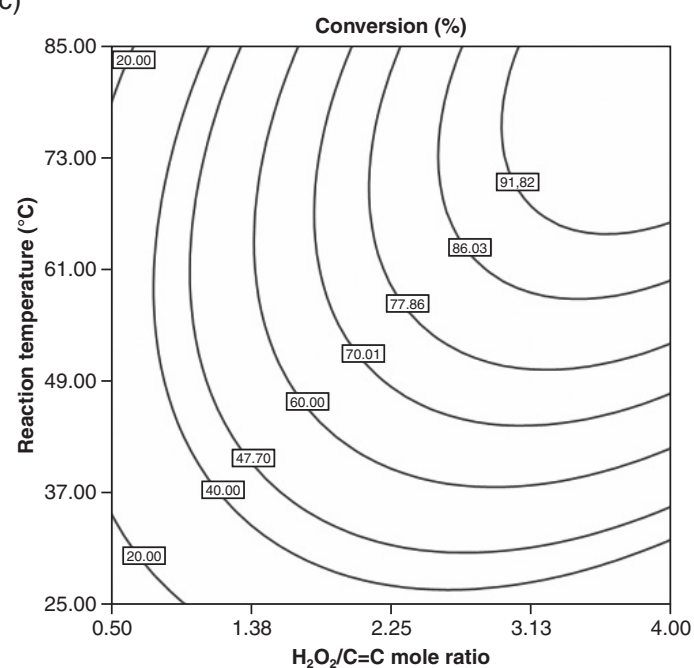

(e)

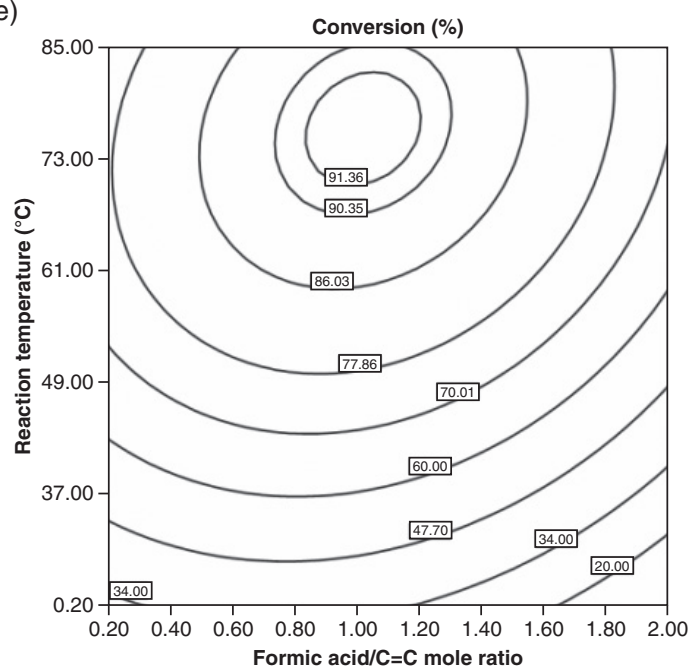

(b)

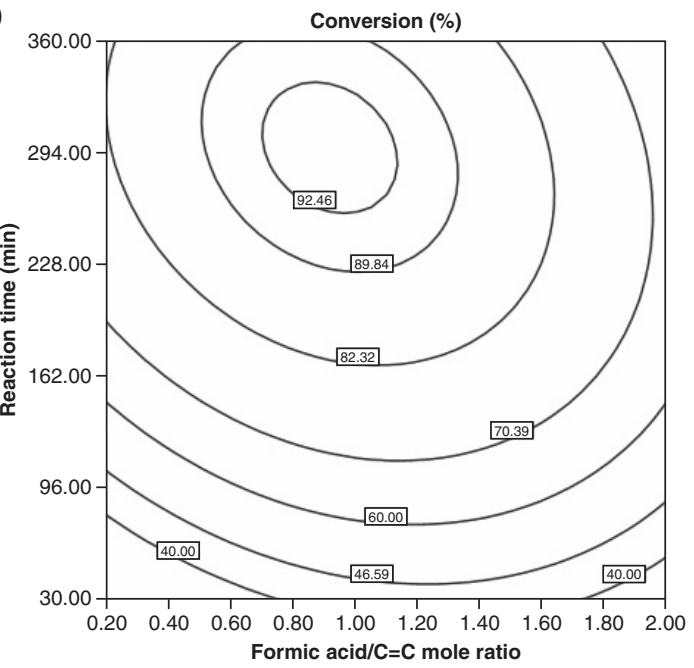

(d)

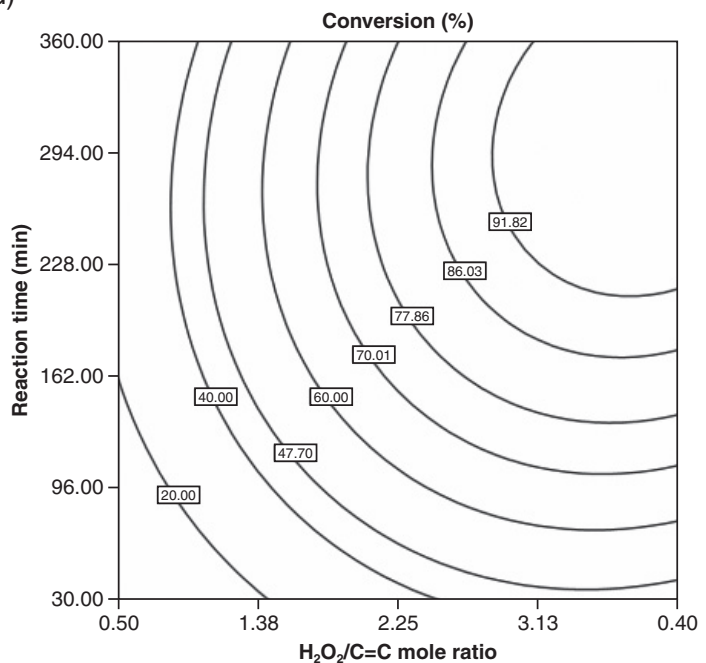

(f)

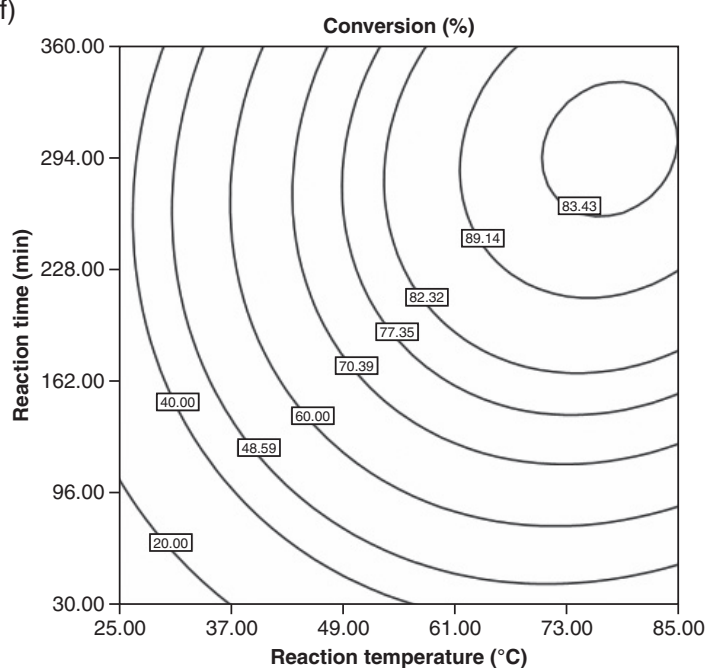

Figure 4

Contour plots of epoxidation yield (\%) predicted from the model.

oxirane generation while the contrary is true for the "regenerating" role of formic acid. Therefore, almost a linear effect in increasing yield can be observed by increasing the hydrogen peroxide amount while increasing the formic acid amount is comparatively less important. However, yield will be very low at very low formic acid amounts and will also be decreasing at excessively high concentrations due to the oxirane ring opening. Optimum conditions can be determined as 3.32 moles of hydrogen 
peroxide $/ \mathrm{C}=\mathrm{C}$ moles and 0.90 moles of formic acid/ $\mathrm{C}=\mathrm{C}$ moles while temperature and time are fixed at $70{ }^{\circ} \mathrm{C}$ and 264 minutes, respectively.

Figure $4 \mathrm{~b}$ represents the effects of the amount of formic acid and reaction time. The effect of the formic acid amount is positive up to a value of about 0.80-1.10 moles $/ \mathrm{C}=\mathrm{C}$ moles and after that it becomes negative. While reaction temperature has a relatively significant and positive effect for up to about 300 minutes, it becomes non-effective after that. Optimum conditions can be assessed at 1.00 moles of formic acid and 307.50 minutes reaction time. Hydrogen peroxide and reaction temperature are fixed at 2.96 moles and $70{ }^{\circ} \mathrm{C}$ respectively.

In Figure $4 \mathrm{c}$ the relationship between the amount of hydrogen peroxide $/ \mathrm{C}=\mathrm{C}$ mole ratio and temperature is shown. It can be observed that the hydrogen peroxide effect is linear over a wide range but the temperature effect is marginally negative at higher values. On the whole, temperature appears to have a more significant effect compared to hydrogen peroxide. Optimum conditions can be assessed at hydrogen peroxide/ $\mathrm{C}=\mathrm{C}$ mole ratio of 3.88 and a reaction temperature of about $67.5^{\circ} \mathrm{C}$. Reaction time and formic acid concentration were fixed at 240 minutes and 1.06 moles, respectively.

Figure $4 \mathrm{~d}$ shows the effect of the varying the amount of hydrogen peroxide $/ \mathrm{C}=\mathrm{C}$ mole ratio and reaction time. Here the variation in the amount of hydrogen peroxide is relatively more significant than the variation in time. An amount of about 3.81 moles of hydrogen peroxide $/ \mathrm{C}=\mathrm{C}$ moles and 300 minutes for reaction time can be found optimum. The formic acid concentration is fixed at $1 \mathrm{~mole} / \mathrm{C}=\mathrm{C}$ moles and reaction temperature was fixed at $70^{\circ} \mathrm{C}$.

Figure $4 \mathrm{e}$ presents the effect of varying reaction temperature against moles of formic $\mathrm{acid} / \mathrm{C}=\mathrm{C}$ moles. The effect of the variation in reaction temperature is more significant as compared to the relative change in formic acid amount. This relationship, once again reveals the ability of the regeneration of formic acid hence variations in its amount are less effective. However, temperature shows its effect on yield by affecting the oxirane generation and oxirane ring opening reactions. Optimum conditions revealed here are 0.95 moles of formic $\mathrm{acid} / \mathrm{C}=\mathrm{C}$ moles and a temperature of $75.51{ }^{\circ} \mathrm{C}$ when hydrogen peroxide concentration and reaction time were fixed at 2.96 moles and 240 minutes respectively.
Figure $4 \mathrm{f}$ explains the effect of varying reaction temperature and reaction time on response. It is obvious that the effect of reaction temperature is more pronounced (more curvature) than that of reaction time. The reaction temperature, up to about $75^{\circ} \mathrm{C}$ has a positive effect and after that the effect becomes negative as the oxirane opening reaction commences. Likewise, at a suitable temperature, reaction time has a positive effect up to about 250 minutes and after that it becomes negative. Optimum temperature and reaction time can be assessed as $72.01{ }^{\circ} \mathrm{C}$ and 295 minutes, respectively while hydrogen peroxide and formic acid are fixed at 2.96 and 1.00 moles respectively.

\subsection{Validation of the model}

An RSM model was employed for the optimization of reaction parameters. The model predicted a maximum yield of oxirane of $94.9 \mathrm{wt}$ \% with a standard error of 1.68 , which can be obtained using 3.12 moles of hydrogen peroxide/ $\mathrm{C}=\mathrm{C}$ moles, 0.96 moles of formic $\mathrm{acid} / \mathrm{C}=\mathrm{C}$ moles, at a reaction temperature of $70.00{ }^{\circ} \mathrm{C}$ for 277.50 minutes of reaction time. The experimental yield using optimized conditions was found to be $92.89 \pm 1.29$ wt. \% which was significantly higher than the previously reported values (Petrović et al., 2002, Campanella et al., 2008a) . When compared to the results inform the literature (Campanella et al., 2008a, Petrović et al., 2002), there is an appreciable difference in the required formic acid quantity. The results are summarized in Table 5. It may be concluded that a lower amount of formic acid requires a longer reaction time to complete the reaction. However, when formic acid is used in higher amounts (e.g. 1 mole), a relatively shorter reaction time gives high conversion, provided that a higher amount of hydrogen peroxide is used. This will make for a quicker and higher conversion on industrial scale which is associated with energy saving.

\subsection{Characterization of Oxiranes}

\subsubsection{FT-IR analysis}

FT-IR bands for methyl esters and epoxy methyl esters are discussed below with their group

Table 5

Epoxidation reaction using different amounts of reactants

\begin{tabular}{lccccc}
\hline \multicolumn{1}{c}{ Study } & $\begin{array}{c}\text { Molar ratios } \mathrm{C}=\mathrm{C} / \\
\mathrm{H}_{2} \mathrm{O}_{2} / \text { Formic acid }\end{array}$ & $\begin{array}{c}\text { Temperature } \\
\left({ }^{\circ} \mathbf{C}\right)\end{array}$ & $\begin{array}{c}\text { Strength } \\
\text { of } \mathrm{H}_{2} \mathrm{O}_{2} \\
(\%)\end{array}$ & $\begin{array}{c}\text { Time } \\
\text { (minutes) }\end{array}$ & $\begin{array}{c}\text { Conversion to } \\
\text { Epoxide } \\
\text { product (\%) }\end{array}$ \\
\hline (Campanella et al., 2008a) & $1 / 2 / 0.5$ & 40 & 59 & 690 & 83.5 \\
(Petrović et al., 2002) & $1 / 1.5 / 0.5$ & 60 & 30 & 300 & $92 \sim 95$ \\
Present study & $1 / 3.12 / 0.96$ & 70 & 30 & 278 & 92.89 \\
Independent experiment performed & $1 / 2.64 / 0.53$ & 65 & 30 & 300 & 75.18 \\
Independent experiment performed & $1 / 2 / 0.5$ & 65 & 30 & 300 & 72.50 \\
\hline
\end{tabular}




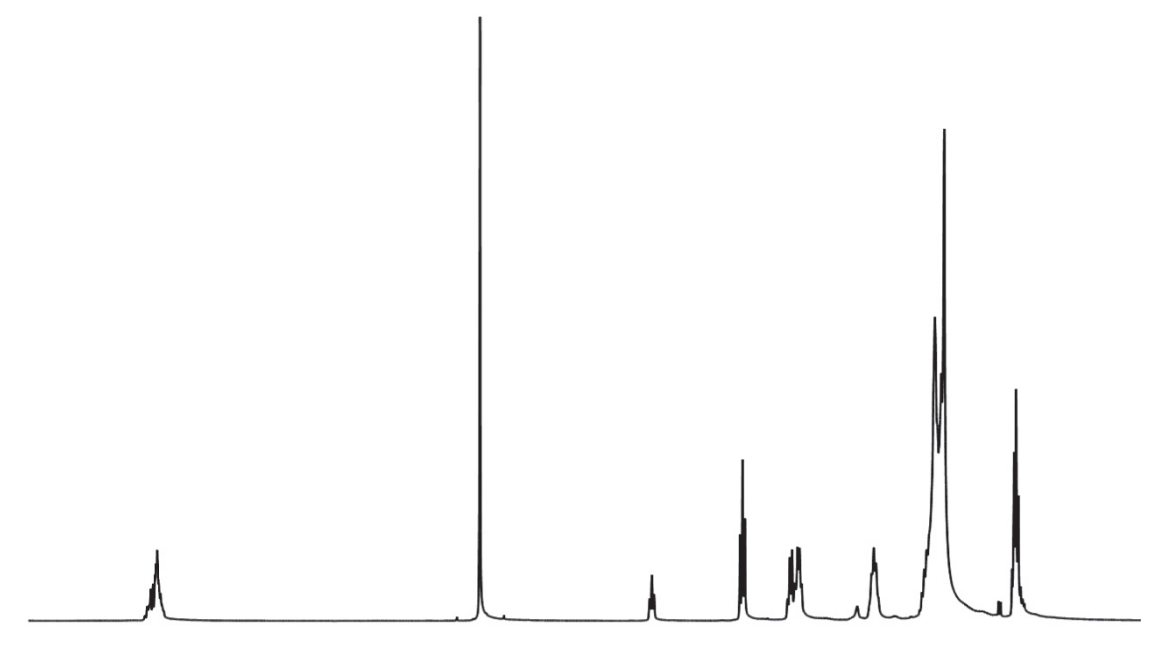

$\begin{array}{lllllllllllllllllllllllllllllllll}6.0 & 5.8 & 5.6 & 5.4 & 5.2 & 5.0 & 4.8 & 4.6 & 4.4 & 4.2 & 4.0 & 3.8 & 3.6 & 3.4 & 3.2 & 3.0 & 2.8 & 2.6 & 2.4 & 2.2 & 2.0 & 1.8 & 1.6 & 1.4 & 1.2 & 1.0 & 0.8 & 0.6 & 0.4\end{array}$ ppm

Figure 5

${ }^{1} \mathrm{H}$ NMR spectrum of methyl esters.

assignments (Vlček and Petrović, 2006, Guillén and Cabo, 1997a, Guillén and Cabo, 1997b).

\section{Methyl esters}

$3006 \mathrm{~cm}^{-1}$ (=C-H cis stretch), $2924 \mathrm{~cm}^{-1}, 2853$ $\mathrm{cm}^{-1}\left(\mathrm{CH}_{2}\right.$ stretch), $1742 \mathrm{~cm}^{-1}$ (ester $\left.\mathrm{C}=\mathrm{O}\right), 1654$ $\mathrm{cm}^{-1}$ (-C=C- stretch), $1459 \mathrm{~cm}^{-1}$ (-C-H bend from $\left.\mathrm{CH}_{2}, \mathrm{CH}_{3}\right), 1435 \mathrm{~cm}^{-1}(\mathrm{C}-\mathrm{H}$ asym. and sym. bend of $\left.\mathrm{CH}_{3}-\mathrm{COO}\right), 1376 \mathrm{~cm}^{-1}\left(\mathrm{CH}_{3}\right.$ sym. bend), 1361 $\mathrm{cm}^{-1}$ (-C-H bend), $1244 \mathrm{~cm}^{-1} 1195 \mathrm{~cm}^{-1}, 1169 \mathrm{~cm}^{-1}$ (ester CO stretch), $1016 \mathrm{~cm}^{-1}$ (O-C-C stretch), 722 $\mathrm{cm}^{-1}\left(\mathrm{CH}_{2}\right.$ rocking).

\section{Epoxy Methyl esters}

$3468 \mathrm{~cm}^{-1}$ (-OH stretch) small band showing opening of ring to give di-hydroxy, $2920 \mathrm{~cm}^{-1}$,
$2854 \mathrm{~cm}^{-1}\left(\mathrm{CH}_{2}\right.$ stretch), $1739 \mathrm{~cm}^{-1}$ (carbonyl stretch), $1459 \mathrm{~cm}^{-1}\left(\mathrm{CH}_{2}\right.$ bend), $1436 \mathrm{~cm}^{-1}(\mathrm{C}-\mathrm{H}$ asym. and sym. bend of $\left.\mathrm{CH}_{3}-\mathrm{COO}\right), 1363 \mathrm{~cm}^{-1}$ $\left(\mathrm{CH}_{3}\right.$ sym. bend), $1246 \mathrm{~cm}^{-1}, 1196 \mathrm{~cm}^{-1}, 1170 \mathrm{~cm}^{-1}$ (ester CO stretch), $1014 \mathrm{~cm}^{-1}$ (O-C-C stretch) 846 $\mathrm{cm}^{-1}, 827 \mathrm{~cm}^{-1}$ (C-O-C epoxide stretch) $723 \mathrm{~cm}^{-1}$ $\left(\mathrm{CH}_{2}\right.$ rocking).

\subsubsection{NMR analysis}

${ }^{1} \mathrm{H}$ NMR is shown in Figures 5 and 6. Details with peak assignments are discussed in the following sections.

\section{Methyl esters}

${ }^{1} \mathrm{H}$ NMR spectrum is shown in Figure 5. Peaks which appeared at $2.06 \mathrm{ppm}$ and at $5.37 \mathrm{ppm}$ are

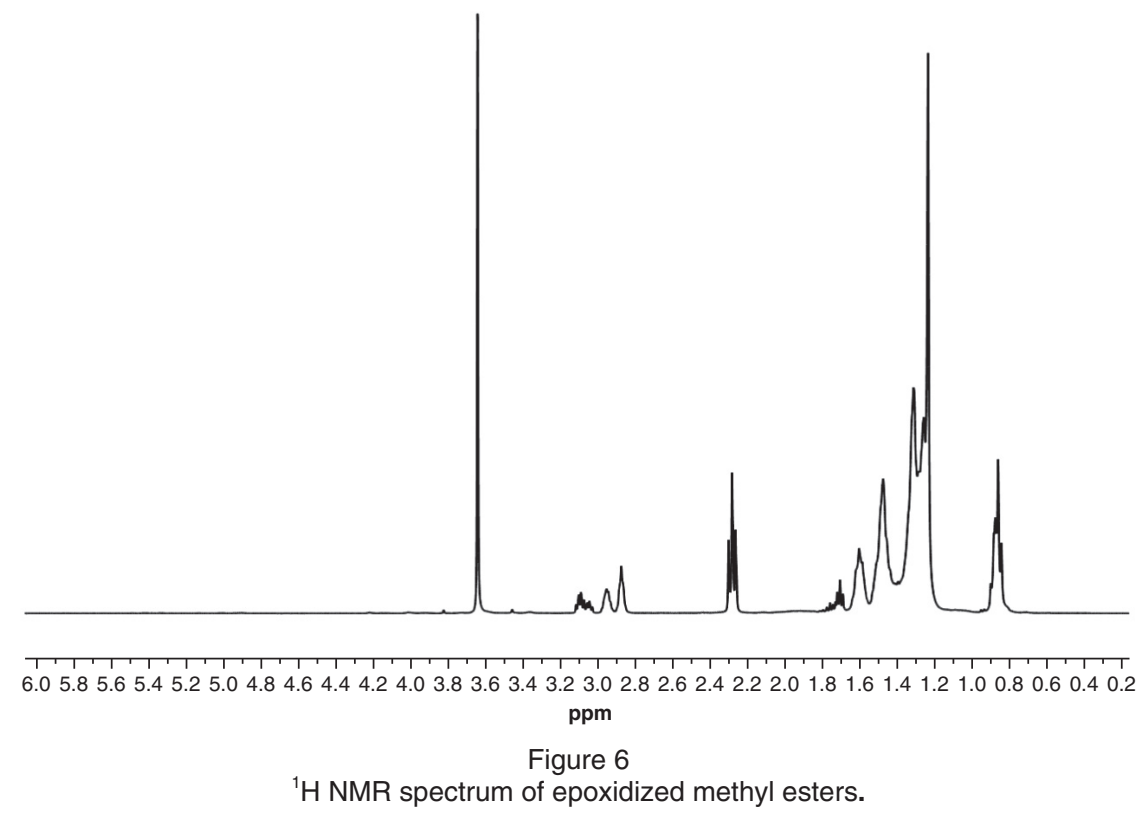


from the protons attached to the carbons having double bonds (Miyake et al., 1998).

${ }^{1} \mathrm{H}$ NMR $\left(\mathrm{CDCl}_{3}\right) \delta$ 0.89-0.93 $\left(-\mathrm{CH}_{3}\right), 1.33-1.63$ $\left(\mathrm{CH}_{2}\right), \quad 1.63\left(\mathrm{CH}_{2}-\mathrm{CH}_{2} \mathrm{COOCH}_{3}\right)$ 2.06-2.07(- $\mathrm{CH}_{2}-$ $\mathrm{CH}=\mathrm{CH}-), 2.28-2.32\left(\mathrm{CH}_{2} \mathrm{COOCH}_{3}\right), 2.82(-\mathrm{CH}=\mathrm{CH}-$ $\left.\mathrm{CH}_{2}-\mathrm{CH}=\mathrm{CH}-\right)$, $3.62\left(\mathrm{C}-\mathrm{OO}-\mathrm{CH}_{3}\right), 5.37(-\mathrm{CH}=\mathrm{CH}-)$.

${ }^{13} \mathrm{C}$ NMR $\left(\mathrm{CDCl}_{3}\right)$ 14.42-14.45 $\left(-\mathrm{CH}_{3}\right), 23.29-$ $34.37\left(\mathrm{CH}_{2}\right), 51.43\left(\mathrm{COOCH}_{3}\right), 128-130(\mathrm{CH}=\mathrm{CH}$, $\left(-\mathrm{CH}=\mathrm{CH}-\mathrm{CH}_{2}-\mathrm{CH}=\mathrm{CH}-\right) 173.97\left(-\mathrm{COO}-\mathrm{CH}_{3}\right)$.

\section{Epoxy methyl esters}

${ }^{1} \mathrm{H}$ NMR analysis confirmed (Aerts and Jacobs, 2004) the presence of mono and di-oxirane rings at $1.51 \mathrm{ppm}, 2.84 \mathrm{ppm}$ and $2.97 \mathrm{ppm}$, as shown in Figure 6 while ${ }^{13} \mathrm{C}$ NMR presented oxirane carbons at $56.74 \mathrm{ppm}$ (not shown). Unsaturation has completely vanished as indicated by the absence of the peaks at $2.06 \mathrm{ppm}$ and $5.37 \mathrm{ppm}$ in ${ }^{1} \mathrm{H}$ NMR spectrum (Figure 5) and at $128-130 \mathrm{ppm}$ in ${ }^{13} \mathrm{C}$ NMR spectrum (not shown).

${ }^{1} \mathrm{H}$ NMR $\left(\mathrm{CDCl}_{3}\right) \delta$ 0.88-0.94 $\left(-\mathrm{CH}_{3}\right), 1.31-1.53$ $\left(\mathrm{CH}_{2}\right), 1.49-1.51\left(-\mathrm{CH}_{2}-\mathrm{CHOCH}-\mathrm{CH}_{2}-\right)$ 1.61( $\mathrm{CH}_{2}$ $\left.\mathrm{CH}_{2} \mathrm{COOCH}_{3}\right), \quad 1.73 \quad\left(-\mathrm{CHOCH}-\mathrm{CH}_{2}-\mathrm{CHOCH}-\right)$ 2.29-2.31 $\left(\mathrm{CH}_{2} \mathrm{COOCH}_{3}\right) 2.84$ (-CHOCH-$), 2.97$ (-CHOCH-CH$\left.{ }_{2}-\mathrm{CHOCH}-\right)$, $3.62\left(\mathrm{C}-\mathrm{OO}-\mathrm{CH}_{3}\right)$,

${ }^{13} \mathrm{C}$ NMR $\left(\mathrm{CDCl}_{3}\right)$ 14.34-14.42 $\left(-\mathrm{CH}_{3}\right)$, 23.28$34.37\left(\mathrm{CH}_{2}\right), 26.8\left(-\mathrm{CHOCH}-\mathrm{CH}_{2}-\mathrm{CHOCH}-\right), 51.43$ $\left(\mathrm{COOCH}_{3}\right), 56.74-59.26$ (- $\left.\mathrm{CHOCH}-\right) 173.94$ (- $\mathrm{COO}-$ $\mathrm{CH}_{3}$ ).

\section{CONCLUSIONS}

RSM based on CCRD was successfully applied for optimizing the reaction parameters for the epoxidation of methyl esters obtained from Jatropha oil using hydrogen peroxide and formic acid. The effects of hydrogen peroxide/ $\mathrm{C}=\mathrm{C}$ mole ratio, formic $\mathrm{acid} / \mathrm{C}=\mathrm{C}$ mole ratio, reaction temperature and reaction time on epoxidation reaction yield were also studied for optimization. A polynomial quadratic model was calculated to predict maximum yield and the optimization of reaction parameters. The model revealed that the epoxidation yield was more sensitive towards the reaction temperature and hydrogen peroxide/ $\mathrm{C}=\mathrm{C}$ mole ratio as compared to formic acid $/ \mathrm{C}=\mathrm{C}$ mole ratio and reaction time. The model was used to optimize the conditions for maximum epoxidation yield. The optimum conditions predicted were at 3.12 moles of hydrogen peroxide/ $\mathrm{C}=\mathrm{C}$ moles, 0.96 moles of formic $\mathrm{acid} / \mathrm{C}=\mathrm{C}$ moles, reaction temperature of $70.00{ }^{\circ} \mathrm{C}$ and 277.50 minutes of reaction time. The model predicted yield was $94.90 \%$. Optimized reaction delivered $92.89 \pm 1.29$ wt. \% yield of epoxidation for methyl esters. The current study successfully reduced the reaction time for the epoxidation reaction to less than five hours by using a relatively higher amount of formic acid for high yield. It can be concluded that the RSM can successfully be utilized to optimize process conditions such as reaction time and to understand the effects and interactions of reaction parameters for the epoxidation reaction on industrial scale.

\section{ACKNOWLEDGMENT}

Financial support of PETRONAS Research Sdn. Bhd. (PRSB) through PRF Project 158200042 and usage of EOR Centre of Excellence facilities is highly acknowledged.

\section{REFERENCES}

Aerts H, Jacobs P. 2004. Epoxide yield determination of oils and fatty acid methyl esters using $1 \mathrm{H}$ NMR. J. Am. Oil Chem. Soc. 81, 841-846.

Anwar F, Zafar SN, Rashid, U. 2006. Characterization of Moringa oleifera seed oil from drought and irrigated regions of Punjab, Pakistan. Grasas Aceites 57, 160-168.

Aslan N. 2008. Application of response surface methodology and central composite rotatable design for modeling and optimization of a multi-gravity separator for chromite concentration. Powder Technol. 185, 80-86.

Brossard-González CO, Ferrari RA, Pighinelli AL, Parka KJ. 2010. Preliminary evaluation of anhydrous ethanol as a solvent in the oilseed extraction of Jatropha curcas L. Grasas Aceites 61, 295-302.

Campanella, A.Baltanás, M. A. 2006. Degradation of the oxirane ring of epoxidized vegetable oils in liquidliquid heterogeneous reaction systems. Chem. Eng. J. 118, 141-152.

Campanella A, Fontanini C, Baltanas M. 2008a. High yield epoxidation of fatty acid methyl esters with performic acid generated in situ. Chem. Eng. J. 144, 466-475.

Campanella A, Fontanini C, Baltanás MA. 2008b. High yield epoxidation of fatty acid methyl esters with performic acid generated in situ. Chem. Eng. J. 144, 466-475.

Dahlke B, Hellbardt S, Paetow MZW. 1995. Polyhydroxy fatty acids and their derivatives from plant oils. J. Am. Oil Chem. Soc. 72, 349-353.

Doll K, Erhan S. 2006. Synthesis and performance of surfactants based on epoxidized methyl oleate and glycerol. J. Surfactants Deterg. 9, 377-383.

Du G, Tekin A, Hammond E, Wood L. 2004. Catalytic epoxidation of methyl linoleate. J. Am. Oil Chem. Soc. 81, 477-480.

Gan L, Goh S, Ooi K. 1992. Kinetic studies of epoxidation and oxirane cleavage of palm olein methyl esters. J. Am. Oil Chem. Soc. 69, 347-351.

Ghadge SV, Raheman H. 2006. Process optimization for biodiesel production from mahua (Madhuca indica) oil using response surface methodology. Bioresour. Technol. 97, 379-384.

Goswami D, Basu JK, De S. 2012. Optimal hydrolysis of mustard oil to erucic acid: A biocatalytic approach. Chem. Eng. J. 181-182, 542-548.

Goud V, Pradhan N, Patwardhan A. 2006. Epoxidation of karanja (Pongamia glabra) oil by $\mathrm{H} 2 \mathrm{O} 2$. J. Am. Oil Chem. Soc. 83, 635-640.

Goud VV, Dinda S, Patwardhan AV, Pradhan NC. 2010. Epoxidation of Jatropha (Jatropha curcas) oil by peroxyacids. Asia-Pac. J. Chem. Eng. 5, 346-354.

Goud VV, Patwardhan AV, Dinda S, Pradhan NC. 2007. Kinetics of epoxidation of jatropha oil with peroxyacetic 
and peroxyformic acid catalysed by acidic ion exchange resin. Chem. Eng. Sci. 62, 4065-4076.

Guillén MD, Cabo N. 1997a. Characterization of edible oils and lard by fourier transform infrared spectroscopy. Relationships between composition and frequency of concrete bands in the fingerprint region. J. Am. Oil Chem. Soc. 74, 1281-1286.

Guillén MD, Cabo N. 1997b. Infrared spectroscopy in the study of edible oils and fats. J. Sci. Food Agric. 75, 1-11.

Ibrahim HM, Abou-Arab AA, Abu-Salem FM. 2011. Antioxidant and antimicrobial effects of some natural plant extracts added to lamb patties during storage. Grasas Aceites 62, 139-148.

Jiang ST, Niu L. 2011. Optimization and evaluation of wheat germ oil extracted by supercritical $\mathrm{CO} 2$. Grasas Aceites 62, 181-189.

Khlebnikova T, Pai Z, Fedoseeva L, Mattsat Y. 2009. Catalytic oxidation of fatty acids. II. Epoxidation and oxidative cleavage of unsaturated fatty acid esters containing additional functional groups. React. Kinet. Catal. Lett. 98, 9-17.

Kleinová A, Fodran P, Brncalová L, Cvengros J. 2008. Substituted esters of stearic acid as potential lubricants. Biomass Bioenerg. 32, 366-371.

Kumar A, Sharma S. 2008. An evaluation of multipurpose oil seed crop for industrial uses (Jatropha curcas L.): A review. Ind. Crop. Prod. 28, 1-10.

Lin B, Yang L, Dai H, Yi, A. 2008. Kinetic Studies on Oxirane Cleavage of Epoxidized Soybean Oil by Methanol and Characterization of Polyols. J. Am. Oil Chem. Soc. 85, 113-117.

Miyake Y, Yokomizo K, Matsuzaki N. 1998. Determination of unsaturated fatty acid composition by highresolution nuclear magnetic resonance spectroscopy. J. Am. Oil Chem. Soc. 75, 1091-1094.
Mungroo R, Pradhan NC, Goud VV, Dalai AK. 2008. Epoxidation of canola oil with hydrogen peroxide catalyzed by acidic ion exchange resin. J. Am. Oil Chem. Soc. 85, 887-896.

Naidir F, Yunus R, Ramli I, Mohd-Ghazi TI. 2011. Response surface methodology for optimization of epoxidized trimethylolpropane ester synthesis from palm oil. Int. J. Chem. React. Eng. 9.

Petrović ZS, Zlatanić A, Lava CC, Sinadinović-Fišer S. 2002. Epoxidation of soybean oil in toluene with peroxoacetic and peroxoformic acids - kinetics and side reactions. Eur. J. Lipid Sci. Technol. 104, 293299.

Rashid U, Ibrahim M, Ali S, Adil M, Hina S, Bukhari I H,Yunus R. 2012. Comparative study of the methanolysis and ethanolysis of maize oils using alkaline catalysts. Grasas Aceites 63, 35-43.

Seniha-Güner F, Yagci Y, Tuncer-Erciyes A. 2006. Polymers from triglyceride oils. Prog. Polym. Sci. 31, 633-670.

Sun S, Ke X, Cui L, Yang G, Bi Y, Song F, Xu X. 2011. Enzymatic epoxidation of Sapindus mukorossi seed oil by perstearic acid optimized using response surface methodology. Ind. Crop. Prod. 33, 676-682.

Vlček T, Petrović Z. 2006. Optimization of the chemoenzymatic epoxidation of soybean oil. J. Am. Oil Chem. Soc. 83, 247-252.

Wilson R, Smith R, Wilson P, Shepherd MJ, Riemersma RA. 1997. Quantitative gas chromatography-mass spectrometry isomer-specific measurement of hydroxy fatty acids in biological samples and food as a marker of lipid peroxidation. Anal. Biochem. 248, 76-85.

Recibido: $27 / 8 / 12$ Aceptado: 12/12/12 